\title{
Part Three, Book One: The Fire or The Eternal Life
}

\author{
Petar Bojanić
}

In the first book of the third part of the Star of Redemption (Stern der Erösung), entitled "The Fire or The Eternal Life," we find, similar to the rest of the books, the problem of a difference between the 1921 and later editions. The first was published during Rosenzweig's lifetime, whereas Nahum D. Galtzer published the second edition, allegedly in accordance with Rosenzweig's instructions, in 1930, shortly after his death, complete with appendices and chapter titles. It would appear that of all the translations into various languages (the most recent was into Russian, appearing in 2017), only the second English translation follows the first edition, although the translator, Barbara E. Galli, retains the titles and subtitles in the margins, so as to facilitate reading. In the first publication of Stern, the book here in question is 47 pages long [SE1, 375-421] and is divided into 60 chapters. Eight of the 60 are capitalized, with the first letter of the book, 'G' (“Gepriesen sei..."), larger than the other seven (E, W, W, D, I, E, U). Overall Stern has only 76 capitalized chapters, each book usually having one, seven or eight. Considered in the context of the whole volume, it might appear as if Rosenzweig's careful calculation yields the word GEWW (Hebraic for 'from within' or 'inside', or else 'from the community' or 'from the home') or DIEU, but this is rather wrongheaded. Of the eight capitalized units in this part ${ }^{251}$

${ }^{251}$ The eight are: Die Verheisung der Ewigkeit (The Promise of Eternity) [SE1 375; SE 331; SG 317]; Das Ewige Volk: jüdisches Schicksal (The Eternal

\section{How to cite this book chapter:}

Bojanić, P. 2021. Part Three, Book One: The Fire or The Eternal Life. In: Brasser, M., Bojanić, P. and Ciglia, F. P. (eds.) The Star for Beginners: Introductions to the Magnum Opus of Franz Rosenzweig. Pp. 145-158. London: Ubiquity Press. DOI: https://doi. org/10.5334/bco.l. License: CC-BY 
(the longest of which is a page and a half long), the first and last play the role of introduction, that is, conclusion to the book. Meaning that six are particularly emphasized in Glatzer-Rosenzweig's intervention. But two units, numbers 5 and 6, capitalized in the first edition have 'reduced significance' in the second: "Soziologie der Gemeinschaft: das Mahl" and "Soziologie des Ganzen: der Gruss" - without the same emphasis as the other six.

How should we read this complicated book? To begin with, what does Rosenzweig wish to achieve with the book and its title, what does he introduce in his introduction? The practice of Judaism in eternity or in eternal life is supposed to be described as a blaze. Yet, the flame (Flamme) or "the heart of the fire" (das Kernfeuer) is special indeed, since it has to burn such that it is never extinguished but always fueled of itself (it needs nothing, it burns nothing other than itself). This pure flame is outside time, regenerates itself and overcomes all forms of time, above all the past and future - in the name of the eternal now. Rosenzweig thematizes time within Judaism several times in the book; the formulation at the top of this chapter, which begins with "Indem so die heilige Gesetzeslehre" (Since teaching of the Holy Law) [SE1 382; SG 323], is not specially marked in the second edition [SE 338] yet is probably the most precise. "The Jewish people does not calculate the years of its own chronology" Life in time is forbidden to the Jewish or holy people, for the sake of eternal life in the eternal now. This is life beyond time or life that does not pass.

To all the better explain these complex structures comprising several rather complicated terms (time, eternity, life, and on the side, self-sustaining fire), throughout the book Rosenzweig distinguishes everything concerning what is 'Jewish' (people, law, language, war, time, etc.) from everyone else (Christianity, other peoples, peoples of the world, etc.). The book, "The Fire or The Eternal Life" is above all a "book of distinctions," helping to clarify often complicated constructions. Thus, Rosenzweig differentiates a community based on blood from one grounded in spirit, will and hope [SE1 376; SE 332; SG 317]. In contrast with Christian peoples, the Jewish people never finds its roots in the land on which it stands [SE1 376; SE 332; SG 318]. As opposed to others, it

People: Jewish Destiny) [SE1 375-383; SE 331-339; SG 317-324]; Das eine Volk: jüdisches Wesen (The One People: Jewish Essence) [SE1 384-387; SE 339-342; SG 324-327]; Das heilige Volk: das jüdisches Jahr (The Holy People: The Jewish Year) [SE1 388-395; SE 342-349; SG 327-334]; Soziologie der Gemeinschaft: das Mahl (Sociology of The Community: The Meal) [SE1 395-403; SE 349-357; SG 334-341]; Soziologie des Ganzen: der Gruss (Sociology of The Whole: The Greeting) [SE1 404-412; SE 357-364; SG 341-347]; Die Völker der Welt: Messianische Politik (The Peoples of The World: Messianic Politics) [SE1 412-420; SE 364-371; SG 348-354]; Der Ewigkeit der Verheisung (The Eternity of The Promise) [SE1 420-421; SE 371-372; SG 354-355]. 
never identifies itself with the language it speaks [SE1 379; SE 334; SG 324]. ${ }^{252}$ Rosenzweig poses the problem of borders, since the Jewish people "can then no longer enclose itself within borders, but it must include the borders within itself" [SE1 384; SE 339; SG 325]. Finally, in contrast with the peoples of the world [die Völker der Welt], the reality of the Jewish people is already realized [SE1 413; SE 365; SG 348], etc.

The entire construction of this book and its meaning could really be an answer to two questions at the beginning of the third unit: "But what does that mean - rooting in ourselves (Verwurzelung im eigenen Selbst)? What does it mean that here an individual or a people seeks the guarantee of its survival (seines Bestehens) in nothing external, and precisely here, precisely in its absence of relationship (Beziehungslosigkeit), wants to be what is eternal" [SE1 384; SE 339; SG 324]? How, then, is an entity constructed or self-constructed? By what means and deploying which strategy, can it be made to be beyond all connection with anything else, yet still last forever and surpass all else? Rosenzweig is here trying to constitute an entirely new "social ontology," in opposition to Hegel's institutionalism and his state-grounding project in general. ${ }^{253}$ Simultaneously working on Stern and his doctoral thesis on Hegel, while also being a participant in one of the most terrible wars in history - thus, Hegel (philosophy), Judaism, and war are the first three elements of Rosenzweig's project, which intertwine, sometimes entirely chaotically, in the book - his intention is to systematize a few concepts that could explain the eternal life of a community. Yet, before that, is it possible to quickly formulate the nature of Rosenzweig's

${ }^{252}$ Rosenzweig brings the second unit to a triumphant close thus: "We alone cannot imagine this sort of time; for everything in which the existence of peoples takes root, has long ago been taken away from us; land language, custom and law long ago departed from the sphere of the living and for us is raised from the living to the holy; but we, we are still living and live eternally. Our life is no longer interwoven with anything external, we have taken root in ourselves, without roots in the earth, eternal wanderers therefore, yet deeply rooted in ourselves, in our own body and blood. And this rooting in ourselves and only in ourselves guarantees our eternity for us" (in uns selbst schlugen wir Wurzel, wurzellos in der Erde, ewige Wanderer darum, doch tief verwurzelt in uns selbst, in unserm eignen Leib und Blut. Und diese Verwurzelung in uns selbst und allein in uns selbst verbürgt uns unsre Ewigkeit). [SE1 383; SE 338-339; SG 324].

${ }^{253}$ Later, in a letter to Martin Buber of 3 July 1925, Rosenzweig pens a complicated sentences that describes the terrible travails of the struggle against institutions in which he condenses his efforts to remain consistent and uncover all the dangers of institutionalism contained in the Jewish heritage. "The struggle against institutions takes all too breath-drainingly long for the tempestuous breath of the prophet" (Kampf gegen Institutionen ist eine viel zu langatmige Sache für den Sturmatem des Profeten). [GS2 1050]. 
institutionalism and its novelty? What is it that he does? I think that the first premise could be that Rosenzweig opposes the institution and state ${ }^{254}$ (Hegel's state, but not only his) with the house. "The chamber of the Jewish heart is at home" [SE1 410; SE 362; SG 346], and it is in the home that begins and ends "the struggle against death" (in the previous section he speaks about marriage and sexual difference). ${ }^{255}$

Franz Rosenzweig speaks of institutions in which there is no life. In two different places in his texts (from the second half of 1919), he presents the confrontation between life and the institution, the house and the institution, all the while (pro)claiming a new institution that is to be an alternative to the university. (He founded his 'counter-institution, "Lehrhaus Forschungsinstitut" in Frankfurt in 1920.) What, then, is a house for Rosenzweig? It ought to protect life and be separated from the city, just as dwelling out to be separated from other city activities.

We can no longer wish to remain naked people. We look 'backward', but not in a way for us to sacrifice our living life to the image of the holy institution that destroys life. No, the institution may only be house, we must know and render true that we are more than an institution, a living Jewish people. (Wir können heute nicht mehr nackte Menschen bleiben wollen. Wir sehen "zurück" aber nicht so, dass wir unser lebendiges Leben wieder dem lebenzerstörenden Bild einer heiligen Institution opfern würden. Nein, die Institution darf uns nur Haus sein, wir müssen es wissen und wahrmachen, dass wir mehr sind als die Institution, lebendige jüdische Menschen). ${ }^{256}$

This passage - from a lecture note - appears as the reconstruction of a fragment from a letter to Rudolf Ehrenberg (of 17 August 1919). In both the letter and the lecture, Rosenzweig goes back and forth. In the letter, he writes:

I do not understand how someone can persist in petrifying people into institutions. We are otherwise happy when able to revive the institution. Here too is real, living, true life good enough to be built into the corner stone of the institution, yet for which no one knows when or even whether it will be built (Ich begreife nicht wie man daran hängen kann,

${ }^{254}$ In his 1920 lecture, "Der Jude im Staat," complete with his reservations towards Zionism, Rosenzweig insists that the state in or for Jews was "nicht lebendig." "Der Jude muss im Staat sein, weil der Staat nicht im Juden sein kann." [GS3 554].

${ }^{255}$ In the following, third, book of Stern, "Die Strahlen oder der ewiger Weg," Rosenzweig is even more precise: "Das ewige Volk ruht schon im Hause des Lebens; die Völker der Welt bleiben auf dem Weg” [SE1 471; SE 397; SG 346].

256 This is a note for the lecture "Lessings Nathan" Rosenzweig held at the end of December 1919. [GS3 450]. 
Menschen zu Institutionen zu versteinern. Sonst ist man froh, wenn man Institutionen menschlich beleben kann. Und hier ist ein wirkliches, lebendiges, tatsächliches Leben grade gut genug dazu, in den Grundstein einer Institution eingemauert zu werden, von der keiner weiss, ob überhaupt und wenn, wie sie gebaut werden wird). ${ }^{257}$

The institution stands in opposition to life (Rosenzweig first separates them, speaking of the 'naked' Institution and naked man), turns life to stone; yet this simultaneously announces the possibility of life not only capable of reviving the institution, but also able to a priori be in the background and in the foundation of some institutions which do not yet exist, which are yet to come, which we await. "We are otherwise happy when able to revive the institution" (Sonst ist man froh, wenn man Institutionen menschlich beleben kann). The institution is not only capable of preserving life (not only ought it protect life), but the reverse is also true: we are the ones capable of preserving the life of the institution, to announce its new life and revive it, to expect it entirely new and alive.

It seems to me that the idea that we alone (Wir allein), our very own common life can constitute a home or an entirely new institution that has all the characteristics of a new and living house (one that does not petrify us, nor that we petrify and move away from). This is the beginning of Rosenzweig's engagement in whose service are all the concepts he uses. ${ }^{258}$ At the very beginning of this book, Rosenzweig anticipate the first person plural, 'We' (a pronoun almost never thematized in the history of Western thought), and this is the introduction into the construction of a community or reconstruction of an eternal community. Indeed, this is the basic theme of this book. Rosenzweig needs to show what it is that holds this community together or what binds us all into one entity, which as such is a priori outside time. The pronoun 'Wir' appears at the beginning of the book in quotations marks, as part of the phrase 'Wir sind ewig', referring to generational transmission, from grandparent to grandson. 'We' thus refers to a blood community, to eternity, common language, and a future that affirms the present. Later in the text, Rosenzweig uses 'Wir allein' several times. In unit six, in which he writes about sin, Wir transforms into a very compact community equated with humanity or mankind (Manschheit), that is, Israel. ${ }^{259}$

257 [GS2 640].

${ }^{258}$ Life is actually the unconditional condition of all that exists, the first concept and the concept that holds all other concepts in order as it constructs it. There is no better sentence about life than the one Rosenzweig writes in the conclusion of the third unit dedicated to "Jewish Essence:" "Aber das lebendige Leben fragt ja nicht nach dem Wesen. Es lebt. Und indem es lebt, beantwortet es sich selbst alle Fragen, noch ehe es sie stellen kann." [SE1 387; SE 342; SG 327].

${ }^{259}$ In his 1922 lectures, published as "Die Wissenschaft vom Menschen," Rosenzweig returns to the Wir. "Mein Ich wird Wir. Im Wir sehe ich mich gleichzeitig von aussen und von innen" [GS3 650]. 
This shift from a speech act to sin that closely binds the individuals of a community into Israel is entirely new and surprising.

Constructing 'Wir' or the phrase "Wir sind ewig" is the axle that holds all other concepts together, giving place to all concepts in a stable order. The various concepts could be divided into a few groups. The first set would include the already mentioned first and crucial articles that determine the difference between Judaism and Christianity. They eminently determine what is Judaism: it is a 'people' ('chosen', 'holy', 'first' - these attributes have complementary function), it is 'blood', always opposed to 'will' and 'spirit', it is (holy) 'language' and writing, it is (holy) 'law', and finally, 'land' or 'territory', which implies "Israel." Everything Rosenzweig wrote at the time with regard to land and territory would today certainly demand complete revision, in the context of the newlyformed state of Israel. Nevertheless, however much the contemporary reader finds Rosenzweig's anti-Zionism hard to understand and perhaps too aggressive and decadent, a hundred years or even seventy years since the founding of Israel, I find his conclusions and arguments still inspiring indeed.

The following group of terms simultaneously directs and revises all the terms, and in a particular way confirms the self-construction of the 'We-axle' or pure flame: this is 'time' or the uses of time and understanding of time always in harmony with eternity. (Rosenzweig insists on an annual cycle that ensures Judaism its eternity; he then further processes all the crucial holy days that regenerate and hold the people together; finally, he constantly mentions the 'present' and 'now', which reflect eternity by excluding the temporality of time.) The group further includes the term 'border', thematized ingeniously in only one place in the book, but further developed in his geopolitical texts from the last period of the war. (A sort of theory of the border in Rosenzweig is a combination of three different sources: Hegel - whose variations on Schranke and Grenze are crucial for understanding his logic and his system in general; Rosenzweig's experience as soldier studying maps and thinks borders in the context of crossing, shifting, fluidity; and Rosenzweig the Talmudist, translator and reader of the world text, always distinguishing and separating significance and meaning.) Finally, the last term in this unit is 'Messiah' ("the future of the Messiah, which is surely drawing near"260) and 'messianism', named in the second to last unit of this book as "messianische Politik," implying the existence of something we might call 'messianic action'.

At the beginning of this unit, Rosenzweig attempts to explain the 'messianic protocol' as such, through an important explanation about the Jewish people, finally "at its goal" (am Ziel): "In the cycle of its year the future is the motive power; the circular movement does not give birth as it were by push (durch

260 “Und die Gesänge des „dritten Mahls", zu dem sich im Dämmer des versinkenden Tages Greise und Kinder am langen gedeckten Tische vereinen, sind ganz trunken von dem Rausch der gewißlich nahenden Zukunft des Messias" [SE1 393; SE 347; SG 332]. 
Stoß), but by tug (sondern durch Zug); the present elapses, not because the past shoves it forward, but because the future drags it along." ${ }^{261}$ Rosenzweig additionally explains the difference between the words Sto $\beta$ and Zug, both carrying multiple meanings, in the second part of the sentence: the present elapses primarily because the future drags it along (die Zukunft sie [die Gegenwart] heranreißt). The future being strength (the future does not contain strength, but is strength, says Rosenzweig) pulls out the present. The construction of this sentence, in which the 'messianic topology', and in general 'messianic action' or 'messianic movement', is 'most clearly' described, can perhaps be part of an ideal introduction into the theory of messianic time. Rosenzweig's contribution and decisive turn is not achieved by simply opposing the strength of the future to that of the past, nor by the substitution of two forms of movement ('pushing' with 'pulling'), but by the use of the word Zug (sondern durch Zug). Rosenzweig's durch Zug assumes a sudden and surprising pulling out of something hidden, something from a hole. 'The messianic' is double: it is always present as hidden in the now ("today is not yet the true 'Today"), and it appears suddenly and from a spasm.

The third and fourth group of concepts is particularly interesting. Rosenzweig incorporates them into the 'We axle' as two dimensions that are new and crucial for the ontology of the eternal flame that constitutes itself. The third group refers to the 'community', and comprises three passages subsequently entitled with 'sociology'. In it, the community is elaborated in detail. (Three other sections of the second book of the third part of Stern are entitled 'sociology.) The fourth group of terms could be reduced to the name 'state' or potentially 'of the world', rather than politics or 'messianic politics'.

Three chapters of the second edition carry titles containing the word 'sociology': "Soziologie der Menge: das Hören" (Sociology of The Crowd: Listening - not capitalized in the original edition), "Soziologie der Gemeinschaft: das Mahl" (Sociology of The Community), and finally "Soziologie des Ganzen: der Gruss" (Sociology of The Whole: The Greeting). These last two have a reduced status in comparison to the other six units of the book. With these three, Rosenzweig is attempting to reconstruct the community (or 'Jewish community') by way of a few sub-concepts. These are 'silence, 'listening', 'meal', 'greeting', 'rest', and 'discipline'. (I believe these terms to be more significant over all the others that occur more than once.) All these protocols produce a network that constitutes a community, connect individuals into a 'We'. Rosenzweig's originality in this respect is to introduce into social ontology something entirely new and surprising, which he has drawn from living Jewish tradition, its laws and mandates.

${ }_{261}$ "In dem Kreislauf seines Jahres ist die Zukunft die bewegende Kraft; die kreisende Bewegung entsteht gewissermaßen nicht durch Stoß, sondern durch Zug; die Gegenwart verstreicht, nicht weil die Vergangenheit sie weiterschiebt, sondern weil die Zukunft sie heranreißt." [SE1 412; SE 364; SG 348] 
'Silence. Even when speaking of holy language, Rosenzweig insists on "the power of silence" (Macht des Schweigens). "With his brother he therefore cannot speak at all; with him the glance informs him better than the word, and there is nothing more deeply Jewish than a final suspicion of the power of the word and a heart-felt confidence in the power of silence." [SE1 380; SE 335; SG 321]. What is the function of the word or of dialogue, and what is role of "mutual silence (das gemeinsame Schweigen)? At the beginning of unit 5, he writes: "Because in eternity the word ceases to exist in the silence of the harmonious gathering (im Schweigen des einträchtigen Beisammenseins) - for we are united only in silence; the word unites, but those who are united grow silent (denn nur im Schweigen ist man vereint, das Wort vereinigt, aber die Vereinigten schweigen) - therefore the burning mirror that collects the sunbeams of eternity in the tiny cycle of the year, the liturgy, must introduce man into this silence" [SE1 388; SE 343; SG 327].

'Listening. The brief chapter "Soziologie der Menge: das Hören" sketches a theory of listening that leads to the community of all who listen a written text. Rosenzweig presents his own experience of lecturing: "The sermon like the text read aloud is itself there to produce the mutual silence of the gathered community (Die Predigt wie der verlesene Text selber ist dazu da, das gemeinsame Schweigen der versammelten Gemeinde zu schaffen). And its essence is therefore not that it is a speech but exegesis; the reading out of the written word is the main thing (die Verlesung des Schriftworts ist die Hauptsache); in it alone the mutuality of the listening (die Gemeinsamkeit des Hörens) and hence the firm ground of all the mutuality of those gathered (Gemeinsamkeit der Versammelten) is produced" [SE1 389; SE 344; SG 329]. Learning how to listen means learning in a way that does not stimulate speaking or the speech of one speaking; rather, listening such that the answer is relinquished while simultaneously encouraging all to listen (each other). "The silent listening (Das schweigende Hören) was only the beginning of the mutual participation" [SE1 395; SE 349; SG 334].

'Rest'. The chapter that speaks of rest (Ruhe) (which also unifies) is specific in that Rosenzweig uses the word 'Einsetzung' to mean Sabbat three times (the word is usually translated with 'institution'), and only on the fourth occasion insisting that in the house "the day of rest instituted" (der Ruhetag eingesetzt) [SE1 395; SE 348; SG 333]. Rest means to reacquaint oneself once again with silence and listening, eschewing idle chatter.

'Meal'. Each of these terms align and gather into a community of all. In the unit entitled "Soziologie der Gemeinschaft: das Mahl" (Sociology of the Community: The Meal) all these terms finally combine to participate equally in the order of the house: "The mutual life (Das gemeinsame Leben) that is thus born is to be a silent life (ein schweigendes Leben), living silence (lebendiges Schweigen); so we can only wait to find it in bodily life (leiblichen Leben). The creation in another way, the exchanging of the out-dated material takes place in the meal. For the individual, eating and drinking are already the new 
birth of the bodily man (leiblichen Menschen). For the community, the meal together (gemeinsame Mahl) is also the treatment in which it is born again to conscious life (bewußten Leben). The silent mutuality of listening and obeying already founds the smallest of communities, that of the home" (Die schweigende Gemeinsamkeit des Hörens und Gehorchens stiftet schon die kleinste Gemeinschaft, die des Hauses). This addition and new term appearing in the home simultaneously with the appearance of the meal and common feast - 'obeying' - is immediately deconstructed, with Rosenzweig insisting that all are equal at the table, that "the mutual life of the home does not live in the mutual obeying." Most importantly, however, at the table, there is no conversation. "Speaking can be done in the street and marketplace with chance meetings; in comparison, a meal together always means a real, realized and active community (eine wirkliche, bewirkte und wirkende Gemeinschaft). In this wordless mutuality in itself of the meal is taken mutually, the mutuality is presented as a real mutual participation animated in life (Gemeinschaft als eine wirkliche im Leben lebendige dargestellt). Where a meal is taken together, there such mutual participation exists. It is so in the home, but so too in monasteries, lodges, casinos, associations. And where mutual participation is lacking, as in classrooms or even in just university lectures, or even seminar practices, it does not exist, although the foundation of mutual participation (das wirkliche Gemeinschaftsleben), the mutual listening is indeed by all means here" [SE1 396; SE 349-350; SG 334].

'Greeting. In the conclusion of the fifth unit, in which he states that during holidays the community celebrates itself at mealtime, Rosenzweig also warns that "mans has as little stopped at the inn of the mutuality of the last silence as in the holidays of the mutual listening" (der Mensch schon in die Gemeinsamkeit des letzten Schweigens eingekehrt). There is something higher, he adds, "and this that is higher may even be located at the outermost border of the mutual participation and be mutuality beyond the mutual life" (und sei dies Höhere auch an der äußersten Grenze der Gemeinschaft gelegen und eine Gemeinsamkeit jenseits des gemeinsamen Lebens) [SE1 403; SE 357; SG 340-341]. What is this 'higher', and what is at the border of the community? Rosenzweig differentiates the silence of listeners to lectures, which is the silence of each individual separately, from the silence during mealtime, in which others cease to be others. "One is greeted when encountered (Man grüßt sich, wenn man sich begegnet). The greeting is the supreme sign of silence (höchste Zeichen des Schweigens): they are silent because they know each other (man schweigt, weil man einander kennt). (...) Only if everything were silent would the silence be perfect and the mutual participation all-mutual (die Gemeinschaft all-gemein). The greeting of all to all (Aller an Alle), wherein this fully mutual silence would show itself, would have, like every greeting would have at least one's announcement and the exchange of a few words, the mutual listening and the mutual meal as the supposition. But how is this greeting of all to all supposed to happen?" (Wie aber soll dieser Gruß Aller an Alle geschehen?) [SE1 403; SE 357-358; SG 341]. 
'Discipline'. Rosenzweig's example of a higher order, disciplined community, one containing "the greeting of all to all" (Aller an Alle) is the military. Soldiers or "comrades" ought to achieve the greatest unity in discipline. This is Rosenzweig's introduction "into the universal mutual participation (Allgemeinschaft) where everyone knows everyone and greets him without words - face to face" (von Angesicht zu Angesicht) [SE1 406; SE 359; SG 343]. 'Discipline' is here a new and auxiliary term that first appears at the moment where Rosenzweig needs to explain what is obedience, mentioning "die Zucht des gemeinsamen Gehorchens geben" (the discipline of mutual obeying). ${ }^{262}$ "But what it does not give is the feeling of freedom that only a mutual life conjures up before the never dwindling background of this mutual discipline (das vor dem nie schwindenden Hintergrunde jener gemeinsamen Zucht: erst ein gemeinsames Leben hervorzaubert). Such a mutual life as it is presented in the meal together is also not yet that which is last, as little as is the listening together (gemeinsame Hören). But on the road of education toward this last, the mutual silence (gemeinsamen Schweigen), this is the second halting-place (die zweite Station), while the listening is the first one" [SE1 397; SE 351; SG 335]. Discipline or a disciplined military as a new and higher constitution of a people as an armed group or a people as an army is condition upon Rosenzweig's remark that common meal determines a people to be free, which instantly opens up the danger of begin destroyed. The community achieved in common mealtime as a symbol of freedom and independence necessarily implies danger. "Not only today have there been rebellions against us to annihilate us, but in each generation back to that first one that migrated from Egypt-and in each generation God has saved us" [SE1 400; SE 353; SG 337].

The fourth group of terms appears in the finale of this book, unit seven, "Die Völker der Welt: Messianische Politik" (The Peoples of The World: Messianic Politics). These are: '(holy) war', 'pacifist' or 'pacifism,' 'people, 'peace,' 'world', 'state', 'right', 'violence'. Rosenzweig's great project on the war is here condensed and abandoned for good in favor of a form of pacifism or a "messianic dilemma" with regard to pacifism that decisively orients the holy people. The war project - let us call it "war" and accept that it was nothing but an ingenious project - was given different code names by Rosenzweig: "Kriegsopera," "Putzianum," "Hansiaca," "Kriegsausgang," and "Kriegsgrund," as well as "Theatrum Europaeum. Ein Versuch über den Schauplatz der Weltgeschichte."263 After many

${ }^{262}$ I have modified the English translation here, replacing the word 'cultivation' with 'discipline'.

${ }^{263}$ In the three letters sent to three different address in the first half of 1917, Rosenzweig explains in detail the origin of his idea for a big book on the war and says he has begun writing, aware that he would be unable to finish the whole project during his time on the front. For us it is certainly important to notice that "Globus," conspicuously longer than the other ten, is the basic part of the first projected book, and that the other texts are miniature 
twists and turns, and many attempts - lest we forget, in August and September 1916, Rosenzweig is convinced that pacifism ought to be abandoned because "ultimate peace" (Endfrieden) is not man's work (Menschenwerk) but a direct act of God (Einwirkung Gottes) [GS1 204], while in December of 1922 he still mentions the inadequacy of believing in pacifism and the power of "spiritual arms" [GS1 874] - perhaps it is now possible to insist on two of Rosenzweig's suggestions. Both suggestions about the role of pacifism in war ("messianic and world war") are based in his acceptance of violence, and the belief that it is really possible to achieve by means of war something not otherwise achievable by peaceful means (based on his theory of two peaces or two kinds of pacifism). Hence, Rosenzweig is completely certain, as is Walter Benjamin for example, that violence can make something (that violence makes a new right or justice, or that by way of violence an old justice becomes some new justice) [SE1 418; SE 370; SG 352-353]. Also, the geopolitical construction helps Rosenzweig claim that only by means of war could the transition of national states and Europe be completed into the planet and the world (war as transition). It also allows him to claim war as a sort of subject (God), deciding on its own beginning, duration and end ("Der Krieg ist der große Entscheider"). ${ }^{264}$ In an unusually important and detailed letter to his parents from 1 September 1916 [GS1 210-214], he writes about peace before (on the brink) of a possible war, that is of peace that exists in paradise (paradiesischen) and of the peace after the war

pieces and portions of that same big book. He tells us that in 1910 or 1911, while writing his thesis on Hegel and the state, he intended to write the history of grounds for war (Kriegsgrund). He hastens to finish his doctorate so as to dedicate himself to this task, since on 25 November 1910, Carnegie established a foundation financing projects that deal with the causes and origins of war. In the three letters of January, March and May of 1917 [GS1 334-335, 375, 395] Rosenzweig offers a few more details: that he wished to analyze wars from 1494 until today, that he is particularly interested in the relationship between the grounds for war (Kriegsgründen) and beginning of war (Kriegsanfängen). He adds that he writes primarily about what is currently taking place, that previously he wished to work in diplomatic archives and examine everything that grounds war, that is, the reasoning that would lead to the beginning of wars. Yet, he also says that he could never write such a book at present, that if he were to write it now, it would be part of some larger book, which demands even more time. Ultimately, this is why he must 'abort' the book...

${ }^{264}$ Cf. Rosenzweig often speaks of war that decides and judges, mostly in the texts "Globus" and "Vox Dei," "Die Gewissensfrage der Demokratie." [GS3 279] "Der Krieg ist ein "göttliches Gericht", aber kein einfaches Strafgericht, sondern "Krisis," Scheidung, Böcke und Schafe" [GS1 350]. In Stern he writes: "Der Krieg allein, der über das Bewußtsein der Einzelnen hinwegrast, entscheidet.” [SE1 416; SE 367-368; SG 351]. 
(or wars) that exists in the time of the Messiah and the thousand year reign. The first peace (the natural state or natural peace), taken care of by the so-called materialist pacifism, is a peace between creations and things that have no connection among themselves, where the frictions and tears are brought to a minimum, and identities and entities are completely separated one from another. In international relations, such a peace is founded on a tolerance of all peoples. The second peace, or the second world peace, the idealistic, messianic (idealistischen, messianischen), around which idealistic pacifism is organized, arrives after the last war. (Rosenzweig notes that it is advocated by German thinkers.) Such peace means a close connection of people and peoples, questions the reasons behind wars, and tries to transform them into reasons for peace and a new life of togetherness. The condition of this new peace and the stake of idealistic pacifism, according to Rosenzweig, is the last war.

This also shows, continues Rosenzweig, that the national and liberal states are in their beginnings (in ihren Anfängen) einen pazifistischen Zug. Both of these formulations, the pessimistic - that pacifism does not achieve true world peace and freedom, but only imperial peace determined by borders and governments, and the optimistic, whereby ("idealistic") pacifism is the part of the war machine that tears down state borders - alter the meaning of the phrase "pazifistischer Zug." The idea (of the national or liberal state) does not contain the $\mathrm{Zug}$, but is the Zug. And it is the Zug at its very beginning, at the moment of its constituting. However, that which is at the beginning of its constitution is also really the beginning of its future end. To be or to have "pazifistischer Zug" means at the end to cease to be or cease having sovereignty - not being a national state. Thus, in a different register, Rosenzweig finds within (the main characteristics of) the state - violence, war, and revolution - precisely those elements that will completely destroy the state. "Pazifistischer Zug," as a deconstructive or affirmative element found within the construction and foundation of the national state itself, is foreshadowed in several places in "The Peoples of the World: Messianic Politics." This is done as Rosenzweig, with surprising inspiration, speaks of the state and of the Jewish people's resistance to having their own state, as well of the Jews (potentially) belonging to the peoples of the world due to this state. He reveals that there is something which contradicts the Jewish people within the state, something alternative, which, paradoxically, has the power to take away eternity from the eternal people. And he confirms the potential of the state to achieve something new and alternative ("if the State could get what it is reaching for"), and as a result "the people have become master over its enemy" [SE1 420; SE 371; SG 354]. Is a possible "Pazifistischer Zug" of the state of Israel not indicated by this?

But who reveals world peace and who is the ideal subject of pacifism? Who should be the agent of this process, according to Rosenzweig?

Opposite this constant life in the war of faith (Glaubenskrieg), the Jewish people has its war of faith behind it in a mythic past. Therefore, all 
wars that is still experiences are purely political wars (rein politische Kriege) for it. And since it does possess the concept of the war of faith, it therefore cannot take them seriously, like the ancient peoples for whom this concept was foreign (fremd). Of course, the Jew is really the only man in the Cristian world who cannot take war seriously, and therefore is the only genuine "pacifist." (...) by living the eternal peace, the Jewish people stands outside of a warlike temporality (kriegerischen Zeitlichkeit); by resting at the goal that it anticipates in hope, it is separated from the march of those who draw near to it in the toil of centuries. ${ }^{265}$

"Der Jude ist der einzige echte 'Pazifist". "Ja der Jude ist eigentlich der einzige Mensch in der christlichen Welt, der den Krieg nicht ernst nehmen kann, und so ist er der einzige echte 'Pazifist." The Jew is the real or the authentic "pacifist," because he cannot take seriously the wars Christian states lead one with another. Twice Rosenzweig underscores that the Jew "cannot" accept or give meaning to these political wars. They are foreign to him because they do not belong to the register or notion (Begriff) of religious wars. Regardless of the fact that in the chapter "War of Faith," which precedes this fragment, he says that as opposed to Christians, the Jewish people knows both types of war, and is the guardian of the knowledge of difference between them, and regardless of the fact that Rosenzweig unveils the possibility of existence of a another, "third" type of war (in which the religious and political are mixed) - the Jewish people remains completely outside the world, and outside "war temporality" (kriegerischen Zeitlichkeit). There are wars between states and peoples (in which peoples risk being annihilated. This is the main characteristic of so-called "political" wars: they are decided in a miraculous, completely mysterious way, by "God's will" or "war alone," and are beyond the consciousness of individuals. Is it really possible that such wars are completely without relevance for Rosenzweig, for a Jew? Did Rosenzweig's entire effort not precisely consist of the attempt to bridge the strict distinction between two kinds of wars within the Jewish political tradition, and to construct or renew the idea of last, messianic wars? If we leave aside his doubts, the dissatisfaction with the end of World War I and his abandonment of the Kriegsgrund project, what does it even mean to disregard political wars and to be the only genuine "pacifist?"

It seems to me that the correct answers to these difficult questions could justify not only the relevance of Rosenzweig's "argumentations" in favor of war (they are rather "argument sketches," intuitions, suggestions), but could also explain another epoch in the history of the Jewish people, which Rosenzweig did not have in mind - the Holocaust, forming of the state of Israel, its wars, new (preventive, asymmetrical) wars for world governance, etc. Although his political manifesto "The Peoples of the World: Messianic Politics" places the Jewish people beyond any state or conflict among states of the world, perhaps it

${ }^{265}$ [SE1 416; SE 368; SG 351]. 
may be possible to defend the consistency and logic of his project by "inscribing" the existence of the state of Israel into it. In the same vein, it seems important to espouse the paradoxical harmony of his project with the changes in the world that happened after his death.

The defense of Rosenzweig's engagement within a complex Jewish political tradition could move in three steps. The first step looks at the statement "Der Jude ist der einzige echte 'Pazifist". Purified of Rosenzweig's ambiguous use of quotation marks over the word pacifist and the controversial proximity of the words genuine and pacifist - is the Jew the only true and authentic pacifist or the only true and authentic "pacifist" (in the latter case, he is the only true pseudo-pacifist, or the real pacifist who is not a pacifist, a "militant pacifist")? - brings us back to the key word der einzige. Only the Jew is the true idealistic pacifist. In that context, the Jew is not interested in purely political wars, but what follows: true "Peace at all cost" which interrupts them. God (war) decides on its end, that is, the Messiah turns political wars into last wars, finally bringing about eternal peace.

Second step: Rosenzweig de facto guards the difference between religious war and ordinary war (gewöhnlichen Kriegs) [SE1 416; SE 367; SG 350]. Nevertheless, he very carefully opens up an uncertain field where this difference could be reduced. The existence of a large world war allows Rosenzweig to construct the idea of a political war or wars that cannot be interrupted before they become last and messianic wars. Only the last war can ever stop, and only when God's will brings it to an end or when the enemy unconditionally accepts peace. This is a novelty in the history of thought and justification of war.

Third step: A new world war, and the existence of the state of Israel and its wars, does not necessarily have to degrade Rosenzweig's project, nor the greatness of a people that was once "its goal." The issue is neither the closing nor the expansion of a particular state, but primarily a new speeding up of world history...the renewal of what Rosenzweig once, a long time ago, called pazifistischer Zug.

\section{Further readings}

Fisher, C., (2012), Contemplative nation. A philosophical account of Jewish theological language, Stanford Univ. Press, Stanford Calif.

Losch, A., (2015), Der Ewige“ als „Synthese“ des Stern. Der Gebrauch des Gottesnamens „der Ewige“ bei Franz Rosenzweig, in: Naharaim 9 (2015) 195-215 [https://boris.unibe.ch/73752/1/naha-2015-0008.pdf]

Rubinstein, E., (1999), An Episode of Jewish Romanticism. Franz Rosenzweig's The Star of Redemption, State University of New York Press, Albany N.Y. 